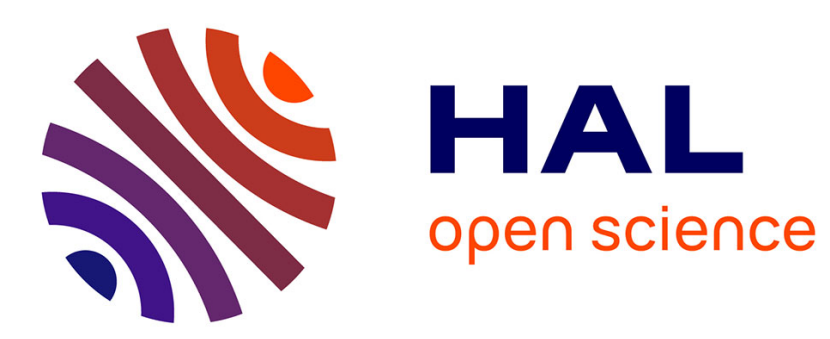

\title{
Influence of water stress on grapevines growing in the field: From leaf to whole-plant response T. Winkel, S Rambal
}

\section{To cite this version:}

T. Winkel, S Rambal. Influence of water stress on grapevines growing in the field: From leaf to whole-plant response. Functional Plant Biology, 1993, 20 (2), pp.143-157. 10.1071/PP9930143 . ird-03373305

\section{HAL Id: ird-03373305 \\ https://hal.ird.fr/ird-03373305}

Submitted on 11 Oct 2021

HAL is a multi-disciplinary open access archive for the deposit and dissemination of scientific research documents, whether they are published or not. The documents may come from teaching and research institutions in France or abroad, or from public or private research centers.
L'archive ouverte pluridisciplinaire HAL, est destinée au dépôt et à la diffusion de documents scientifiques de niveau recherche, publiés ou non, émanant des établissements d'enseignement et de recherche français ou étrangers, des laboratoires publics ou privés. 


\title{
Influence of Water Stress on Grapevines Growing in the Field: from Leaf to Whole-plant Response
}

\author{
T. Winkel ${ }^{\mathrm{AB}}$ and S. Rambal ${ }^{\mathrm{AC}}$ \\ A Centre National de la Recherche Scientifique, \\ Centre d'Ecologie Fonctionnelle et Evolutive-Louis Emberger, \\ BP 5051, F-34033 Montpellier Cédex, France. \\ ${ }^{B}$ Present address: O.R.S.T.O.M., BP 11416, Niamey, Niger. \\ C Corresponding author.
}

\begin{abstract}
A comparative study of soil-plant water relations was conducted on three grapevine cultivars (Vitis vinifera $\mathrm{L}$. cvv. carignane, merlot, shiraz) to investigate their adjustment to short-term and long-term water stress under field conditions. Adjustment was a function of the relative stability of the internal plant water status on diurnal and seasonal scales. On a diurnal scale, stomatal closure in response to water vapour pressure directly contributed to this stability. Indirect evidence suggested an influence of the soil water status on the diurnal stomatal activity. On a seasonal scale, sufficient leaf hydration required high whole-plant hydraulic conductance. This was achieved by either daily stomatal regulation or limitation of leaf area. Physiological adjustment to water stress through stomatal control was well developed in cv. carignane, which originated in a Mediterranean environment. However, cv. shiraz, which was of mesic origin, apparently adjusted to water stress by reducing leaf area. Our study demonstrates the utility of integrating data on stomatal conductance, leaf water potential and wholeplant hydraulic conductance to interpret whole plant adaptation to water stress, and elucidates two mechanisms by which genotypes differentially acclimate to water stress.
\end{abstract}

\section{Introduction}

There is a great deal of evidence which indicates that, for several plant species, the daily minimum value of leaf water potential remains in a narrow range even among different genotypes and under contrasting environmental conditions (Jarvis 1976; Aston and Lawlor 1979; Whitehead et al. 1984; Schulze 1986; Saliendra and Meinzer 1989; Tenhunen et al. 1989). This value changes in the short term, mainly in response to solar radiation, but also in the long term, i.e. crop development, in response to seasonal change of environment. However, as Salleo and Lo Gullo (1985) pointed out for Mediterranean species, the seasonal decrease in leaf water potential is often on the same order of magnitude as the diurnal decrease during a warm sunny day. For these plants, the level of leaf hydration appears to be limited within certain constraints which maintain internal water status (Jarvis 1975; Meidner 1983).

The only mechanisms by which plants achieve homeostasis in internal water status are changes in the conductance of their water pathways (Meidner 1983). The question which then arises is, what strategy can these plants develop to at least partially avoid exposure to water stress. This necessarily refers to the temporal variations of the plant water status, which can be characterised by two major cycles: firstly, a daily cycle with maximum evaporative demand near solar noon, and secondly, an annual cycle with maximum water stress occurring during the summer drought in temperate and Mediterranean climates. Plant responses to the constraints imposed by these cycles take place at two different levels (Schulze et al. 1987b): 
(i) instantaneous control of transpirational flux via the stomata; and (ii) the ability to survive drought periods of several weeks, which depends on the long-term water relations between whole plant and the soil.

The first level has been extensively investigated for many species and in particular grapevine. Physiological studies carried out on potted or field-grown vines have shown the dependence of stomatal activity on solar radiation, air vapour pressure deficit (Düring 1976; Lange and Meyer 1979; Giulivo and Ramina 1981) and, more recently, on soil water status (Natali et al. 1985; Beran 1987; Düring 1987). This detailed knowledge has allowed the development of empirical models of stomatal activity (e.g. Winkel and Rambal 1990). However, such models remain of limited interest to understanding the water relations in the canopy as a whole. Passioura (1986) stated that the short-term effects of water deficits may have only a trivial influence on overall plant growth. Nevertheless, stomatal control may contribute strongly to the regulation of canopy transpiration, especially in vineyards, which are aerodynamically rough surfaces with high boundary layer conductance (Riou et al. 1987).

The second level, that is, the whole-plant functioning as an integrated process, remains almost unknown (Schulze et al. 1987a), especially under field conditions. This comes in part from the lack of data on the long-term dynamics of morphological parameters, such as those controlling the root/shoot ratio in relation to seasonal variations of water availability. A further difficulty arises from the complex feedbacks between root and shoot which complicate understanding of whole plant water relations (Schulze 1986) by overriding some underlying mechanisms (e.g. stomatal closure in response to ABA without decrease in leaf water potential). Whole-plant hydraulic conductance could be used for the analysis of the diurnal and seasonal variations in stomatal conductance (Meinzer et al. 1988) or water use efficiency (Calkin and Pearcy 1984). Meinzer and Grantz (1990), calculating stomatal and hydraulic conductances on a total leaf area basis, demonstrated how the coordination of these two hydraulic parameters could help to maintain plant water homeostasis of sugarcane. In all these studies, the analysis of the temporal patterns of soil-plant water conductivity was needed to take into account the interactions between water regime and carbon partitioning, particularly with respect to root growth. Recent studies on the hydraulic properties of grapevine twig sections (Salleo and Lo Gullo 1985; Salleo et al. 1985; Sperry et al. 1987) have shown the propensity of the xylem vessels to become air-filled with increasing water flux. At a more integrative level, Liu et al. (1978) concluded, from a 1 day data set, that grapevine roots were the main source of resistance to liquid flow in whole plants. However, after studying the hydraulic resistance of young potted vines during a 14 days drying cycle, Schultz and Matthews (1988a, 1988b) concluded that the shoot component of soil-plant resistance was significant and variable. They further concluded that cavitation of the xylem could restrain vegetative growth even at moderate water deficits. However, to our knowledge, the functional relationships developed throughout an entire annual cycle between hydraulic transport and vegetation growth of field grown vines have not yet been investigated.

The purpose of this paper is to explore in the field the adaptation of various grapevine cultivars to water stress on a whole plant basis; on both diurnal and seasonal scales.

\section{Materials and Methods}

The study area was located at two sites in the Aude valley, southern France $\left(43^{\circ} 13^{\prime} \mathrm{N}, 2^{\circ} 50^{\prime} \mathrm{E}\right)$. A detailed site description was given in Winkel and Rambal (1990). Four vineyards were studied at the two sites with soils of contrasting water retention capacity (calculated from field capacity and minimum water storage measured in 1986-87).

(a) The first site, located on the flood plain $1.6 \mathrm{~km}$ from the Aude river, represented the wet site of our study (loamy soil texture, available soil water of $180 \mathrm{~mm}$ for the $0-130 \mathrm{~cm}$ layer). Experimental plots were planted with carignane grafted on R110, and merlot grafted on SO4. 
(b) The second site, $3.8 \mathrm{~km}$ away, was on a Quaternary stony terrace, and characterised by a thick calcareous hardpan at $80-120 \mathrm{~cm}$ depth (available soil water of $120 \mathrm{~mm}$ for the $0-130 \mathrm{~cm}$ layer). Plots were planted with cvv. carignane and shiraz both grafted on R110.

The carignane, merlot and shiraz cultivars originate, respectively, from Aragon (Spain), the Bordeaux region and the Rhône valley (France). These geographical origins cover a climatic gradient from Mediterranean semi-arid (carignane) to mesic (shiraz) with the merlot at an intermediate position. Since vines were between 6 and 15 years old, their root systems were assumed to have reached maximum extension. Carignane vines were goblet-pruned, while merlot and shiraz were cordon trained. The planting density was 3300 plants $\mathrm{ha}^{-1}$, except for the carignane plot on the wet site where it was 4000 plants $\mathrm{ha}^{-1}$.

Field measurements were made on the following dates: 12 May, 13 June, 27 June, 9 July, 15 August 1986; 24 May, 2 June, 9 July, 11 September and 21 October 1987. Diurnal variations in leaf water potential $\left(\psi_{\mathrm{L}}\right)$, stomatal conductance $\left(g_{\mathrm{s}}\right)$, transpiration flux (TR), air temperature and humidity, and global radiation were recorded on two different vines per plot at each date. Leaf water potential was determined on three fully sunlit leaves in the middle of the shoots using a pressure chamber (PMS 1000, PMS Inst.). Stomatal conductance and transpiration flux were measured on six sunlit leaves located in the middle of the shoots using a steady-state porometer ( $\mathrm{Li} \mathrm{1600,} \mathrm{Li-COR}$ ).

Meterorological data were obtained from shielded thermistors and capacitive hygrosensors, which were placed at.c. $2 \mathrm{~m}$ height at both sites to determine air temperature and humidity from which water vapour pressure deficit was calculated using the formula of Henderson-Sellers (1984). Global radiation was measured from a pyranometer installed on the wet site. Daily precipitation was registered $500 \mathrm{~m}$ away from the plots on the dry site and was considered to be representative of the two study sites.

Soil volumetric water content of each plot was measured with a neutron moisture gauge to a depth of $130 \mathrm{~cm}$ on the wet site and $190 \mathrm{~cm}$ on the dry site. Data recorded between 20 May and 8 July 1986 enabled an estimate of root water uptake by vines to be determined for successive soil layers. The assumptions made for this calculation were: (i) only the iupper $10 \mathrm{~cm}$ of soil was influenced by the evaporation process and, due to cultivation practices, did not contain roots; (ii) the very low precipitation at this time period ( $<10 \mathrm{~mm} / \mathrm{month}$ ) was immediately evaporated; and (iii) water drainage and redistribution between soil layers was negligible during the summer period.

Vegetative growth of the vine was measured in the four plots on six dates from bud burst (10 April 1987 ) to leaf fall (20 October 1987). Following Carbonneau (1976a, 1976b), the total leaf area per plant was assessed in a non-destructive way from both the relation 'single leaf area/sum of the lengths of the two lateral nervures' and the estimation of the mean number of leaves per plant at each date. The regression between leaf area $\left(A, \mathrm{~cm}^{2}\right)$ and nervures length $(L, \mathrm{~cm})$ was calculated from a single sample of 314 leaves taken from the four plots throughout the growing season $\left(A=0.95 L+0 \cdot 32 L^{2}\right.$, $\left.r^{2}=0.99, P<0.01\right)$. The mean number of leaves per vine was estimated from three or four plants per plot on each date. The derivative of the curve relating the total leaf area against time was used as a measure of the mean daily growth rate of the foliage area $\left(\mathrm{m}^{2}\right.$ leaves day ${ }^{-1}$ plant $\left.^{-1}\right)$.

Total hydraulic conductance between soil and leaf $\left(C_{\mathrm{SL}}\right)$ was calculated from the relation:

$$
\mathrm{TR}=C_{\mathrm{SL}} *\left(\psi_{\mathrm{L}}-\psi_{\mathrm{b}}\right),
$$

with the assumption that predawn leaf water potential $\left(\psi_{\mathrm{b}}\right)$ is equivalent to the mean soil water potential in the root zone. In order to fulfil the requirements of permanent water flux assumed by this relation, the only measurements of TR and $\psi_{\mathrm{L}}$ taken into account were those made when $\psi_{\mathrm{L}}$ varied by less than 0.2 MPa (typically between 10:30 and 15:30 Local Solar Time), i.e. when a dynamic equilibrium between absorption and transpiration fluxes was established [see discussion of this method in Liu et al. (1978) and Schultz and Matthews (1988b)].

\section{Results and Discussion}

\section{Expression of Water Homeostasis}

Fig. 1 presents on both seasonal and diurnal scales, the leaf water potentials $\left(\psi_{\mathrm{L}}\right)$ pooled for all plants in the four plots over the 2 years of study. Daily minimum values of leaf water potential $\left(\psi_{\min }\right)$ showed a simple seasonal trend with a peak near $-2.0 \mathrm{MPa}$ at the end of the summer period (Fig. 1a). Despite differences in climate for the 2 years, and the varied soil/cultivar combinations, the range of $\psi_{\min }$ at a given time did not exceed $0.5 \mathrm{MPa}$. 

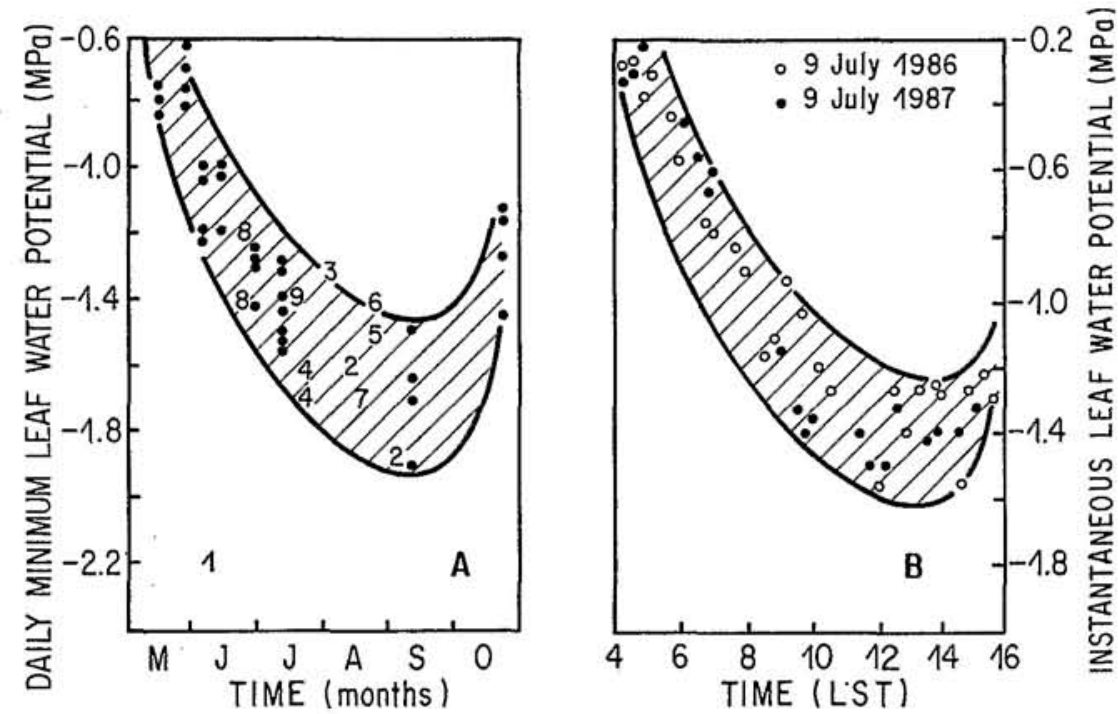

Fig. 1. Seasonal and diurnal variations of leaf water potential in field-grown vines. Points are daily minimum values $(A)$ or instantaneous values $(B)$ measured on four plots in 1986-1987. Numbers refer to leaf water potentials given in the literature $(1,2$, Chaves and Rodrigues 1987; 3, Downton et al. 1987; 4, Düring and Loveys 1982; 5, Katerji and Daudet 1986; 6, Kliewer et al. 1983; 7, Klepper 1968; 8, Loveys and Düring 1984; 9, Smart 1974).

Values of $\psi_{\min }$ reported in the literature for non-irrigated vines growing under field conditions ( 2 to 9 in Fig. $1 a$ ) are well within the range observed in the present study. However, these values represent an even broader range of climatic conditions, soil moisture levels, cultural practices, cultivars, plant ages etc. This suggests that there may be a physical barrier restraining $\psi_{L}$ values of field grown grapevines within the dashed zone of Fig. $1 a$ which is independent of environmental conditions. However, Chaves and Rodrigues (1987a) measured $\psi_{\min }$ of $-2 \cdot 2 \mathrm{MPa}(1$ in Fig. $1 a$ ) and even $-3.0 \mathrm{MPa}$ on potted water-stressed vines that fully recovered after rewatering. Thus, grapevine has the potential to survive much stronger short-term water stress than that commonly experienced in the field.

Fig. $1 b$ shows the instantaneous values of $\psi_{\mathrm{L}}$ recorded during two sunny days in the summer. Pooling the data from the different plots and years showed a degree of consistency in the leaf water status of the grapevine. Following the diurnal course of the sun, $\psi_{\mathrm{L}}$ dropped from $-0.2 \mathrm{MPa}$ at dawn to $-1.7 \mathrm{MPa}$ at noon, with an instantaneous range (dashed zone width) of about $0.5 \mathrm{MPa}$ throughout the day.

Thus, as reported by Salleo and Lo Gullo (1985) for three Mediterranean species, it appears that grapevine experiences both slow (seasonal) and rapid (diurnal) changes in leaf water potential, with the same order of magnitude in both cases (about $1.5 \mathrm{MPa}$ ). It is as if, whatever the time-scale characteristic of the water constraint (diurnal cycle of evaporative demand or seasonal variations in soil moisture and air dryness), the leaf water status of vines growing in the field, even under Mediterranean climate and without irrigation, would remain within the narrow bounds necessary to maintain adequate leaf metabolism. In this respect, it is worth noting that net photosynthesis of grapevine remains unaffected until $\psi_{\min }$ values are about $-1.5 \mathrm{MPa}$, and then decreases sharply (Kriedemann and Smart 1971; Chaves 1981). 


\section{The Daily Cycle of Leaf Functioning}

Fig. 2 compares the diurnal courses of leaf water potential and stomatal conductance $\left(g_{s}\right)$ observed for the two carignane plots on 3 days representative of the summer period.

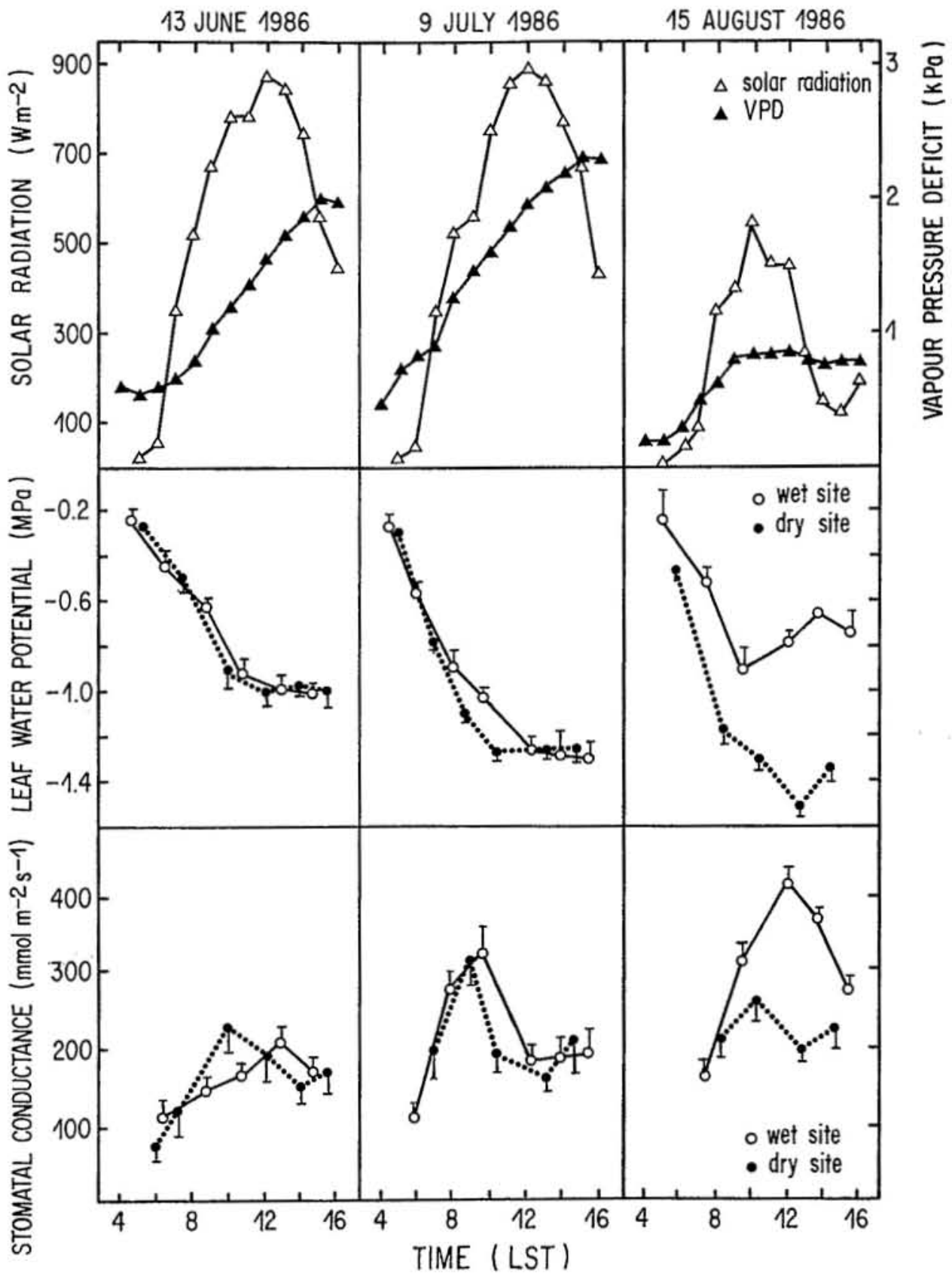

Fig. 2. Diurnal courses of weather conditions, leaf water potential and stomatal conductance for grapevines (cv. carignane) on wet (open symbols) and dry sites (solid symbols). The standard error is plotted unless eclipsed by the symbol. 
The diurnal variations of climatic factors (global radiation, vapour pressure deficit) are also presented.

For sunny days in early summer, the plant water status did not differ between the two sites (mean differences of $0.07 \mathrm{MPa}$ on 13 June, $0.12 \mathrm{MPa}$ on $9 \mathrm{July}$, not significant at $P<0 \cdot 05$ ). On 9 July, stomatal conductance followed a similar trend at both sites, i.e. it rapidly increased after sunrise, then decreased at mid-morning and remained fairly constant until late afternoon. However, the stomatal closure was faster for the vine on the dry site and, as shown by the data of 13 June, stomatal regulation on this plot also occurred earlier in the season. This illustrates how the same leaf water status may correspond to very contrasting plant water relations. At the wet site, the diurnal course of $g_{s}$ with a maximum on midday remained strongly linked to the atmospheric factors, whereas as the dry site, maintenance of a $\psi_{\mathrm{L}}$ value of $-1.0 \mathrm{MPa}$ involved the regulation of the transpirational flux by means of a partial stomatal closure at midday.

Data from the end of summer showed that leaf water status remained the same only in a certain range of water stress. On 15 August 1986, after 14 weeks of drought ( $40 \mathrm{~mm}$ of precipitation since $1 \mathrm{May}$ ), the predawn leaf water potential reached $-0.5 \mathrm{MPa}$ at the dry site and, despite the cloudy conditions and the very low VPD $(0.8 \mathrm{kPa}$ at 1200 hours $)$, the vine dehydrated severely $\left(\psi_{\min }=-1.5 \mathrm{MPa}\right)$ and the stomata partially closed at noon. In contrast, for the vine growing on the wet site, the stomatal opening did not undergo any limitation and the high soil water content, suggested by a $\psi_{\mathrm{b}}$ value of $-0.2 \mathrm{MPa}$, permitted an increase in $\psi_{\mathrm{L}}$ at midday.

These daily patterns of $g_{\mathrm{s}}$ and $\psi_{\mathrm{L}}$ parallel those described by Turner et al. (1984) and Meinzer et al. (1988), and clearly show that the diurnal variations in $g_{s}$ cannot be simply attributed to the influence of $\psi_{\mathrm{L}}$. The same is true for the relationship between $g_{\mathrm{s}}$ and VPD, as indicated by the data of the dry site. It also suggests that, besides physiological and weather variables, the leaf water relations are partly mediated by soil and/or whole-plant hydraulic factors.

\section{Seasonal Whole-plant Water Cycle}

Fig. 3 shows the daily values of predawn and minimum leaf water potential $\left(\psi_{\mathrm{b}}\right.$ and $\psi_{\min }$ respectively), as well as the midday and maximum values of the stomatal conductance ( $g_{\text {mid }}$ and $\left.g_{\max }\right)$ measured on the four experimental plots in 1986.

On both wet and dry sites, the carignane vine showed the highest seasonal variations in $g_{\max }$. Without water stress (wet site), $g_{\max }$ increased throughout the season from 150$200 \mathrm{mmol} \mathrm{m}^{-2} \mathrm{~s}^{-1}$ in May up to $450-500 \mathrm{mmol} \mathrm{m}^{-2} \mathrm{~s}^{-1}$ at the end of the summer, then declined again as the leaves senesced $\left(250 \mathrm{mmol} \mathrm{m}^{-2} \mathrm{~s}^{-1}\right.$ in October 1987, data not shown). Data collected in both years during the summer period (June-September), show that $g_{\max }$ of carignane was independent of the site but, in both locations, was significantly higher than for the other cultivar (Table 1). Over the same time period (except on 15 August 1986 and 11 September 1987), the midday value of $g_{\mathrm{s}}$ remained fairly constant for the different days and plots at around $200 \mathrm{mmol} \mathrm{m} \mathrm{m}^{-2} \mathrm{~s}^{-1}$. As a consequence, the carignane vine showed the strongest stomatal regulation (difference between $g_{\max }$ and $g_{\text {mid }}$ ), particularly in comparison with the shiraz vine (Table 1, Fig. 3): on a sunny day, this regulation could reach $200 \mathrm{mmol} \mathrm{m}^{-2} \mathrm{~s}^{-1}$ for the former, while it never exceeded $50 \mathrm{mmol} \mathrm{m}^{-2} \mathrm{~s}^{-1}$ for the latter. Thus, there are indications of a differential plasticity in stomatal functioning amongst the experimental plots, and the similarity of the values measured on both carignane sites (Table 1) suggests that this plasticity is a varietal characteristic, unaffected by the contrast in soil conditions.

The ability of the carignane vine to actively control its daily transpiration flux via stomatal closure certainly forestalled possible fluctuations in internal water status during the dry season. Such stomatal activity was less developed in the other two cultivars, and yet they did not undergo stronger water stress: their values of $\psi_{\min }$, though generally lower, 

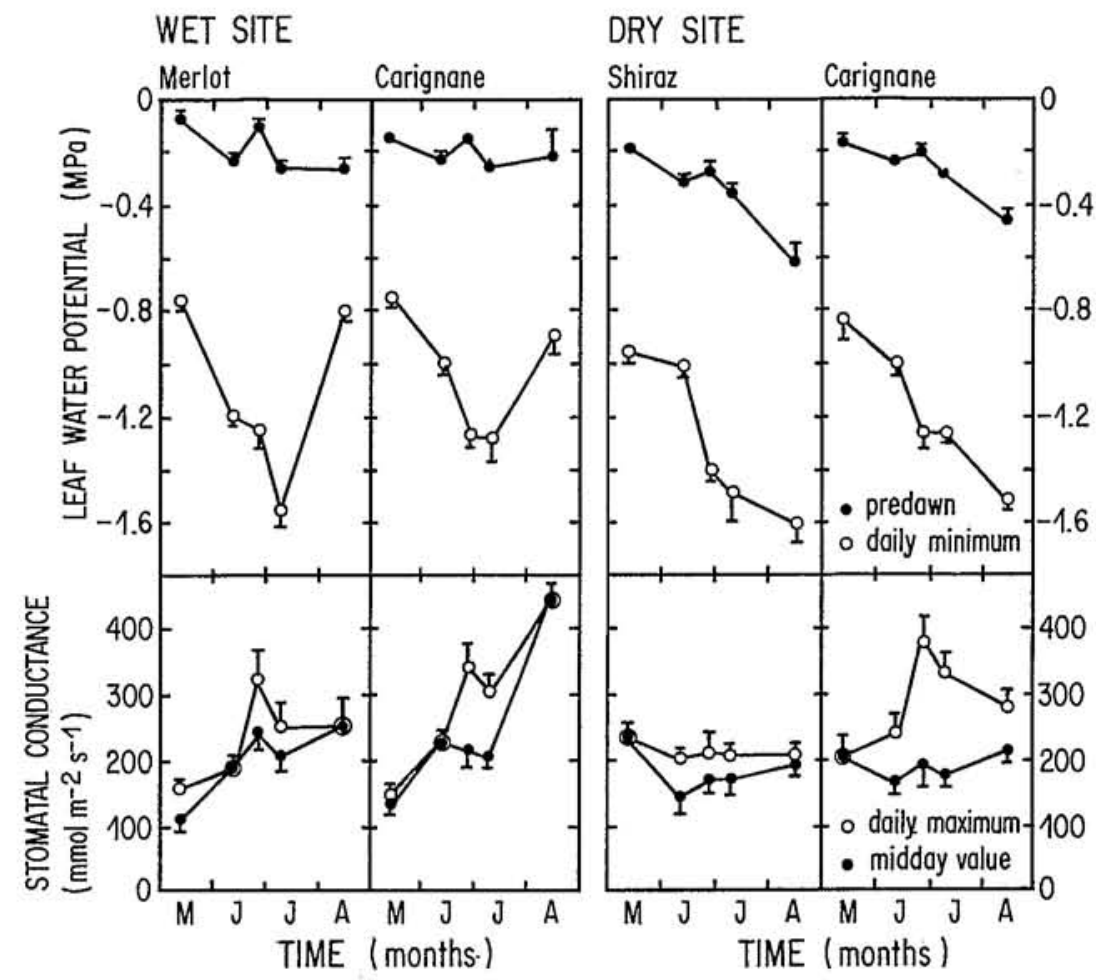

Fig. 3. Seasonal courses of daily minimum and predawn leaf water potentials, and daily maximum and midday stomatal conductances on the four plots in 1986. The standard error is plotted unless eclipsed by the svmbol.

Table 1. Mean differences in stomatal conductance and leaf water potential between experimental plots during the June-September period (data from 1986-1987)

$g_{\text {max }} \cdot g_{\text {mid }}$ : respectively, daily maximum and midday values of stomatal conductance $\left(\mathrm{mmol} \mathrm{m} \mathrm{m}^{-2} \mathrm{~s}^{-1}\right) ; \psi_{\min }$ : daily minimum leaf water potential $(\mathrm{MPa})$; *, **: significantly different from zero at the 5 and $1 \%$ levels respectively

\begin{tabular}{lccc}
\hline $\begin{array}{c}\text { Wet site } \\
\text { carignane-merlot }\end{array}$ & $\begin{array}{c}\text { Dry site } \\
\text { carignane-shiraz }\end{array}$ & $\begin{array}{c}\text { Carignane plots } \\
\text { wet site-dry site }\end{array}$ \\
\hline$g_{\text {max }}$ & $61 \cdot 3^{*}$ & $111 \cdot 2^{*}$ & $37 \cdot 0$ \\
$g_{\text {mid }}$ & $30 \cdot 7$ & $20 \cdot 7$ & $76 \cdot 0$ \\
$g_{\max }-g_{\text {mid }}$ & $30 \cdot 6$ & $84 \cdot 3^{* *}$ & $55 \cdot 7$ \\
$\psi_{\text {min }}$ & 0.06 & $0 \cdot 11$ & $0 \cdot 10$ \\
\hline
\end{tabular}

were not significantly different from those of the carignane vine on the same site (Table 1, Fig. 3). Since stomatal behaviour alone cannot be invoked to explain the similarity in plant water status of the four experimental plots, the total soil-leaf hydraulic conductance was calculated as an index of the water functioning at the whole-plant level.

Fig. 4 shows the seasonal changes in hydraulic conductance $\left(C_{\mathrm{SL}}\right)$ comparing the two carignane plots. Estimations of the 2 years have been reported on the same graph for a better visualisation of the seasonal responses. This figure also shows the mean daily growth rate 


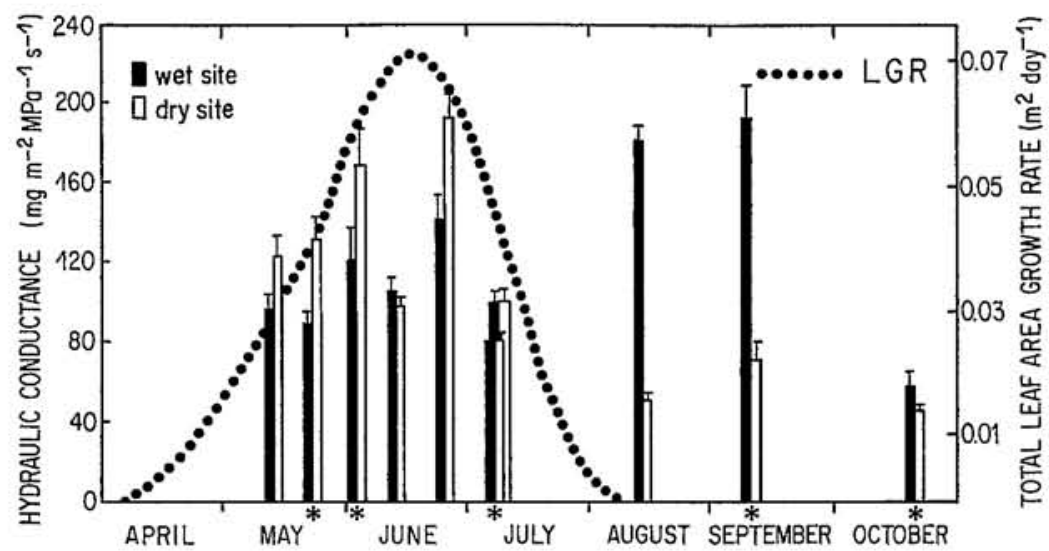

Fig. 4. Seasonal courses of total leaf area growth rate (dotted line), and of soil-leaf hydraulic conductance for grapevines (cv. carignane) on wet (black) and dry sites (white). Stars show data collected in 1987, others are from 1986. The standard error is plotted unless eclipsed by the symbol.

of the total leaf area per plant (LGR) measured on these plots in 1987. In vines on the dry site, $C_{\mathrm{SL}}$ had a single-peaked seasonal pattern increasing continuously from May until the end of June, then decreasing by almost $50 \%$ in early July, and declining slowly over the remainder of the season. At the wet site, the pattern was more complex. Following a similar trend as at the dry site until early July, $C_{\mathrm{SL}}$ reached high values in August and September, and then converged again with $C_{\mathrm{SL}}$ at the dry plot at the end of the season.

Three stages can thus be distinguished on this annual cycle. The first period (from bud burst until the end of June) corresponds to the spring growing season, during which the leaf area growth rate rose to a maximum of $0.07 \mathrm{~m}^{2} \mathrm{~d}^{-1}$ per plant. Assuming that in grapevine, as in other plant species (Rogers and Head 1969; Montenegro et al. 1982), the productions of new roots and leaves are closely correlated, the increase in $C_{\mathrm{SL}}$ during this period may result from the reduction in the root component of plant hydraulic resistance by rapid root extension in a still well-watered soil. The second period begins in early July with a sharp decrease in $C_{\mathrm{SL}}$ on both sites. At this time, LGR has'dropped to about $50 \%$ of its maximum in June, while the mean total leaf area per plant has reached $90 \%$ of its value at full development. Such a decrease in $C_{\mathrm{SL}}$ occurring early in the drying cycle coincides with the inhibition of leaf and shoot growth. This point will be discussed further.

Later in the summer, considerable divergence in the plant hydraulic properties occurred in the two plots. As early as August, $C_{\mathrm{SL}}$ in the dry plot fell to a level comparable to that observed subsequently in October (about $50 \mathrm{mg} \mathrm{m}^{-2} \mathrm{~s}^{-1} \mathrm{MPa}^{-1}$ ), whereas on the wet plot, $C_{\mathrm{SL}}$ in August and September rose to almost $200 \mathrm{mg} \mathrm{m}^{-2} \mathrm{~s}^{-1} \mathrm{MPa}^{-1}$. Such a difference reflects the contrast in water regime between the two plots. At the dry site, the soil water storage declined continuously over the summer period (-19 $\mathrm{mm}$ between 9 July and 15 August 1986, $-31 \mathrm{~mm}$ between 9 July and 11 September 1987 , in the $10-190 \mathrm{~cm}$ soil layer), while on the wet site, important flood irrigations on the adjacent plots resulted in the maintenance of a nearly constant soil water storage $(+2.2 \mathrm{~mm}$ and $+2.5 \mathrm{~mm}$ for the same time periods as above, in the $10-130 \mathrm{~cm}$ soil layer).

The last phase of this annual cycle is illustrated by the data of October 1987. Despite the high soil water content, $C_{\mathrm{SL}}$ stayed at very low values in both sites. This could be due to the physiological changes accompanying leaf senescence (Kriedemann 1978; Field 1987), and may also be due to damage on the shoots and leaves at the time of the grape harvest. 
It is noteworthy that the values of $C_{\mathrm{SL}}$ on the wet site at the end summer were of the same order as those found on the dry site at the end of the active growing phase. It appears that, in the case of sufficient soil water resource, $C_{\mathrm{SL}}$ will remain constant, at a level determined by the functional equilibrium between the fully grown vines and their substrate. This maximum $C_{\mathrm{SL}}$ could hold a predictive value since it appears nearly identical over the two measurement years. Then, the daily transpiration rate of the vine could be estimated from equation (1) by integrating the diurnal course of the leaf water potential. Table 2 gives the values calculated on a unit leaf area basis for the two carignane plots on 3 days in 1986. These values compare well with those obtained by directly integrating the instantaneous TR fluxes measured by the porometer, and thus support the hypothesis of a constant $C_{\mathrm{SL}}$ throughout the day. The transpiration rates estimated by Liu et al. (1978) $\left(3.5 \mathrm{~L} \mathrm{~m}^{-2} \mathrm{~d}^{-1}\right)$ and Larsen et al. (1989) $\left(0.95 \mathrm{~L} \mathrm{~m}^{-2} \mathrm{~d}^{-1}\right)$ bracket our values, which could provide useful indices of the water requirements of grapevines under field conditions.

Table 2. Daily transpiration rates $\left(\mathrm{L} \mathrm{m}^{-2} \mathrm{~d}^{-1}\right)$ of the carignane vines estimated (a) from equation 1 by integrating daytime leaf water potential, and (b) by integrating the transpiration fluxes measured with a porometer

\begin{tabular}{lcccccc}
\hline & \multicolumn{2}{c}{ 13 June 1986} & \multicolumn{2}{c}{9 July 1986} & \multicolumn{2}{c}{ 15 August 1986} \\
& $(a)$ & $(b)$ & $(a)$ & $(b)$ & $(a)$ & $(b)$ \\
\hline Wet site & $3 \cdot 0$ & $2 \cdot 3$ & $4 \cdot 0$ & $4 \cdot 4$ & $3 \cdot 4$ & $2 \cdot 6$ \\
Dry site & $2 \cdot 8$ & $3 \cdot 0$ & $4 \cdot 0$ & $4 \cdot 3$ & $1 \cdot 7$ & $2 \cdot 1$ \\
\hline
\end{tabular}

Comparison of $C_{\mathrm{SL}}$ between the four plots over the active growing phase, the subsequent drying period or the entire season shows generally significant difference for the vines on the wet site, while the shiraz vine did not differ from the carignane vine on the dry site (Table 3).

Table 3. Mean differences in $C_{\mathrm{SL}}\left(\mathrm{mg} \mathrm{m}^{-2} \mathrm{~s}^{-1} \mathrm{MPa}^{-1}\right)$ amongst experimental plots for each of three time periods (data from 19861987)

*, ***: significantly different from zero at the 5 and $0.1 \%$ levels respectively

\begin{tabular}{lcc}
\hline Time period & $\begin{array}{c}\text { Wet site } \\
\text { merlot-carignane }\end{array}$ & $\begin{array}{c}\text { Dry site } \\
\text { shiraz-carignane }\end{array}$ \\
\hline May-June & $22 \cdot 4^{*}$ & $10 \cdot 2$ \\
July-September & $27 \cdot 2$ & $8 \cdot 9$ \\
May-October & $24 \cdot 7^{* * *}$ & $6 \cdot 1$ \\
\hline
\end{tabular}

With similar foliage areas in both plots (Table 4), the constantly lower $C_{\mathrm{SL}}$ values in the merlot vine compared to the carignane plot may mainly reflect the comparative effectiveness of their respective root systems to acquire and transport water. Water uptake from successive soil layers (in percentage of the total water uptake for a given period) reveals contrasting patterns in the two plots (Fig. 5). For the carignane vine, the main zone of water uptake shifted downwards as the upper soil layers became progressively dry from May to July. Such pattern is promoted by the rootstock (R110), known to penetrate the soil to great depth. For the merlot vine, the root water uptake over the same time period appears to be mainly located in the upper $70 \mathrm{~cm}$ of the soil profile (Fig. 5). In this case, the rootstock (SO4) spreads more superficially than does the R110. The lower planting density, resulting 
in lower inter-individual competition, may also encourage such a rooting pattern in the merlot plot. However, the capacity of this superficial root system to supply leaves with water may be exceeded during the hours of high evaporative demand (Meinzer et al. 1988), thus leading to systematically lower hydraulic conductance.

Table 4. Seasonal changes in total leaf area per plant $\left(\mathrm{m}^{2}\right)$ measured on the experimental plots in 1987

Numbers in parentheses are leaf area indices (leaves $\mathrm{m}^{2} /$ soil $\mathrm{m}^{2}$ )

\begin{tabular}{|c|c|c|c|c|}
\hline \multirow{2}{*}{$\begin{array}{c}\text { Date } \\
\text { (1987) }\end{array}$} & \multicolumn{2}{|c|}{ Wet site } & \multicolumn{2}{|c|}{ Dry site } \\
\hline & Merlot & Carignane & Shiraz & Carignane \\
\hline 30 April & $0.3(0.1)$ & $0.4(0.2)$ & $0.1(0.05)$ & $0.2(0.1)$ \\
\hline 2 June & $1 \cdot 2(0.4)$ & $1 \cdot 8(0 \cdot 8)$ & $1 \cdot 2(0.4)$ & $1.8(0.6)$ \\
\hline 9 July & $3 \cdot 5(1 \cdot 2)$ & $3.9(1.6)$ & $3 \cdot 4(1 \cdot 1)$ & $4 \cdot 1(1 \cdot 4)$ \\
\hline 28 July & $4 \cdot 3(1 \cdot 4)$ & $3 \cdot 8(1 \cdot 6)$ & $3 \cdot 7(1 \cdot 2)$ & $4 \cdot 4(1 \cdot 5)$ \\
\hline 20 October & $3 \cdot 4(1 \cdot 1)$ & $3 \cdot 4(1 \cdot 4)$ & $3 \cdot 1(1 \cdot 0)$ & $4 \cdot 2(1 \cdot 4)$ \\
\hline
\end{tabular}

Grapevines growing at the dry site were both grafted on R110. Data show similar rooting patterns, with roots extending well below $2 \mathrm{~m}$ (Fig. 5). Allowing for the contrasting stomatal behaviours of shiraz and carignane, lower values of $C_{\mathrm{SL}}$ would be expected for the shiraz vine. Yet, this is not the case and the explanation thus seems to lie at the whole-plant level. Throughout the year, the total leaf area was significantly lower $(P<0.05)$ for the shiraz than for the carignane vine, by $33 \%$ on 2 June 1987 , and still $16 \%$ on 27 July 1987 (Table 4). With deep roots supplying water to a reduced foliage area, the shiraz vine could compensate for its poor stomatal regulation by maintaining high values of the whole-plant water conductance and, in this way, maintain leaf water status.
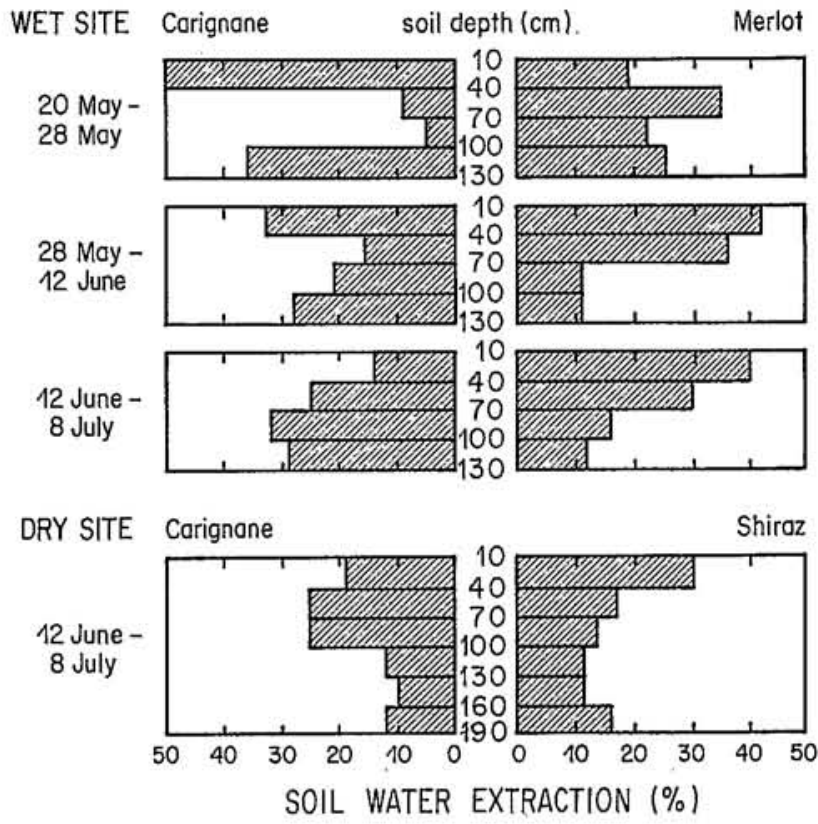

Fig. 5. Vertical distribution of root water uptake in the four plots over different time periods (\% of total water uptake in the given period). 


\section{Relationship between Water Relations and Plant Growth}

The relationship between changes in water relations and plant growth inhibition can be discussed further by relating plant hydraulic properties to the data on vine leaf area collected on the four plots in 1987.

The maximum stomatal conductance per unit leaf area $\left(g_{\max }\right)$ increased sharply in small plants, then slowed down above a total leaf area of about $2 \mathrm{~m}^{2}$ per plant (Fig. 6). The three cultivars followed the same relationship, whatever the water regime $(y=313$ $\left.[1-\exp (-0.65 x)], r^{2}=0.98, n=12, P<0.01\right)$. Only the data from September and October were outside the curve (Fig. 6, open circles), perhaps due to the impact of the leaf senescence on stomatal behaviour.

The stomatal conductance per plant (the product of $g_{\max }$ and total leaf area) increased linearly as the plants grew, again with the same relation in the four plots (Fig. 7, $y=$ $\left.333.4 x-192 \cdot 7, r^{2}=0.99, n=12, P<0.01\right)$. The daily maximum transpiration flux per plant also rose linearly with the leaf area $\left(y=6.05 x-1.89, r^{2}=0.93, n=12, P<0.01\right.$, data not shown). It was apparently unaffected by the alteration of stomatal activity observed during plant growth (see Fig. 6).

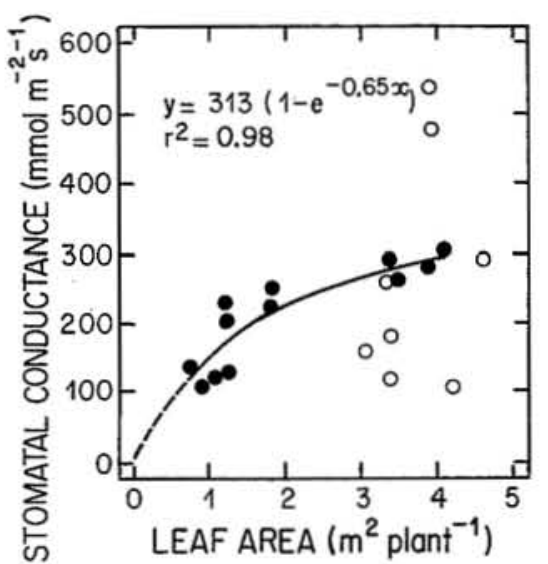

Fig. 6. Daily maximum stomatal conductance per unit leaf area versus plant leaf area. Each point represents the mean of six measurements. Open circles show data collected on 11 September and 20 October 1987.

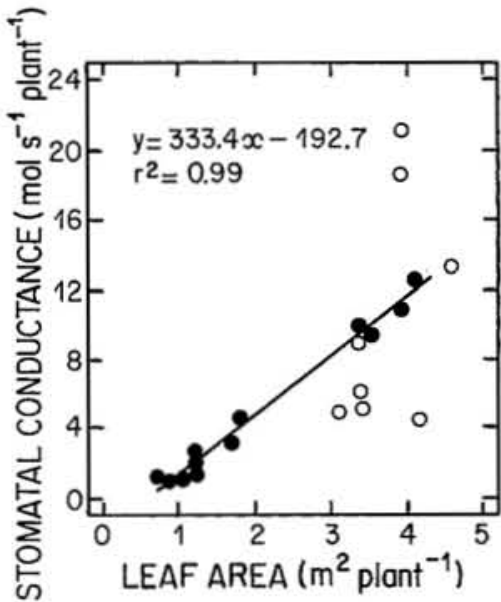

Fig. 7. Daily maximum conductance per plant versus plant leaf area (same remarks as for Fig. 6).

The changes in hydraulic conductance per plant (data not shown) parallel those of $g_{\max }$ shown in Fig. 6. In both cases, the slope of the relation became less steep as the plant leaf area rose beyond $2 \mathrm{~m}^{2}$ per plant. On the other hand, Fig. 8 shows that the stomatal and hydraulic conductances, both calculated on a total leaf area basis, remained proportional on the first part of the graph only: beyond a $C_{\mathrm{SL}}$ of approximately $220 \mathrm{mg} \mathrm{MPa} \mathrm{MP}^{-1} \mathrm{~s}^{-1}$ per plant, the conductance at the leaf-atmosphere interface increased more rapidly than did the ability of the root-shoot system to absorb and transport water. The break in the proportionality between these water transfer parameters occurred when the plant leaf area reached about $2 \mathrm{~m}^{2}$ per plant. This value, showing a critical point for the water relations during vine growth, coincides with the mean ordinate of the inflexion point of the logistic curves describing the seasonal variation in total leaf area on the four experimental plots 
(i.e. $2 \cdot 04 \mathrm{~m}^{2}$ per plant, s.e. $=0 \cdot 08$ ). Thus, the decrease in the leaf growth rate occurring in mid-June was associated with deep changes in the water relations at the whole-plant level. This observation on field grown vines confirms the results obtained by Schultz and Matthews $(1988 a, 1988 b)$ on potted vines, showing that a slight increase in hydraulic resistance can appreciably reduce the shoot growth rate. Their studies demonstrate that cavitation of the xylem vessels by air bubbles occurs, even in well-watered vines, during the hours of rapid transpiration. These authors suggest that this phenomenon is the main reason for shoot growth inhibition since it severely restrains water transport towards extending tissues.

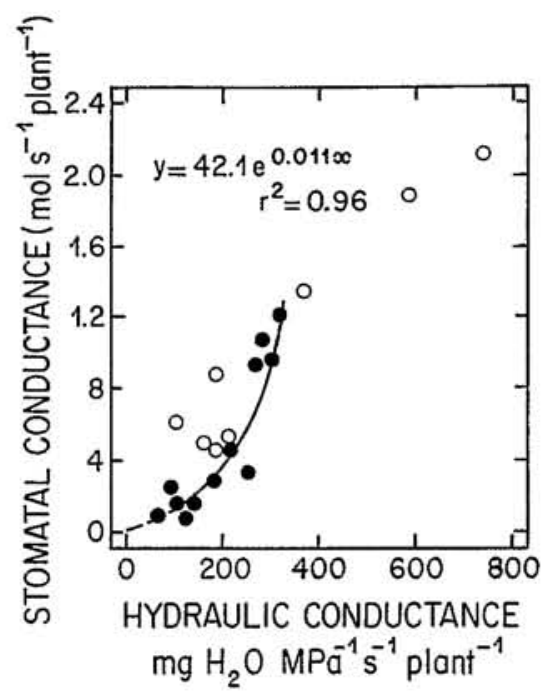

Fig. 8. Stomatal conductance per plant versus total hydraulic conductance.

\section{Conclusion}

This study has shown the highly specific ability of different cultivars to react at the two levels where a plant can modify its transpirational flux, that is, the stomata and the whole root-leaf conductive system.

Midday stomatal closure allows for the optimisation of available water on a daily scale, which results in a high carbon gain (Farquhar et al. 1980; Hall and Schulze 1980), may sustain extra root growth and hence, contribute to drought avoidance by continued water extraction in the absence of rain (Turner 1986). Sensitivity to air humidity strongly determines this stomatal regulation. In a previous study (Winkel and Rambal 1990), we found differential stomatal sensitivity to air humidity in the various cultivars. This is confirmed by the present work, demonstrating that the carignane vine (originating in Aragon) maintained over the whole season the highest capability for instantaneous control of the transpiration flux, while the shiraz (native of the Rhône Valley) showed the weakest capability. Such findings are consistent with the comparative drought resistance commonly ascribed to these cultivars.

For drought-adapted plants, midday stomatal control helps to prevent xylem cavitation during hours of high evaporative demand and also promotes root growth by increased water use efficiency. Thus, stomatal regulation provides a powerful mechanism assuring a high conductivity for the water through the whole plant by forestalling cavitation and hence a reduction in $C_{\mathrm{SL}}$. However, for plants like the shiraz vine, which lack efficient stomatal control, high values of $C_{\mathrm{SL}}$ under water deficit are maintained through a reduction of the 
transpiring surface. Water homeostasis certainly has adaptive significance since it enables plants to perform well under water stress. For grapevine particularly, it ensures the maintenance of a leaf water potential that is not detrimental to carbon assimilation (Kriedemann and Smart 1971; Chaves 1981).

Interpreting processes as adaptation to environment, we conclude this study with the following hypothesis: under drought conditions, grapevine cultivars of mesic origin would tend to maximise their water resources by morphological plasticity (leaf area reduction), whilst Mediterranean cultivars would conserve water by physiologically adapted processes (stomatal regulation) resulting from selection in chronically dry habitats.

\section{Acknowledgments}

We thank M. Maistre, M. Grandjanny, J. C. Jacquinet and the agricultural advisers of the Chambre d'Agriculture de l'Aude for their invaluable help with fieldwork. The review and comments of W. Payne (ICRISAT) on the manuscript were sincerely appreciated. This study was conducted with the support of the Programme Interdisciplinaire de Recherches sur l'Environnement (PIREN) of the C.N.R.S. (Grant Nos 8682-613, 8760-5069 and 8860-5053) and of the Programme 'Zones Sèches Méditerranéennes'.

\section{References}

Aston, M. J., and Lawlor, D. W. (1979). The relationship between transpiration, root water uptake and leaf water potential. Journal of Experimental Botany 30, 169-81.

Beran, N. (1987). Der Einfluss der Temperatur und der Bodenwassergehalten auf der Blattdiffusionwiderstand der Rebe (Vitis vinifera L.). Die Wein-Wissenschaft 6, 363-82.

Calkin, H. W., and Pearcy, R. W. (1984). Leaf conductance and transpiration, and water relations of evergreen and deciduous perennials co-occurring in a moist chaparral site. Plant, Cell and Environment 7, 339-46.

Carbonneau, A. (1976a). Principes et méthodes de mesure de la surface foliaire. Essai de caractérisation des types de feuilles dans le genre Vitis. Annales d'Amélioration des Plantes 26, 327-43.

Carbonneau, A. (1976b). Analyse de la croissance des feuilles du sarment de vigne: estimation de sa surface foliaire par échantillonnage. Connaissance de la Vigne et du Vin 10, 141-59.

Chaves, M. (1981). Photosynthetic characteristics and environmental control in some grapevine cultivars. In 'Components of Productivity of Mediterranean-Climate Regions. Basic and Applied Aspects'. (Eds N. S. Margaris and H. A. Mooney.) pp. 105-13. (Junk: The Hague.)

Chaves, M. M., and Rodrigues, M. L. (1987a). Photosynthesis and water relations of grapevines growing in Portugal. Response to environmental factors. In 'Plant Response to Stress. Functional Analysis in Mediterranean Ecosystems'. (Eds J. D. Tenhunen et al.) pp. 379-90. NATO ASI Series G, Vol. 15. (Springer Verlag: Berlin.)

Chaves, M. M., and Rodrigues, M. L. (1987b). Water-stress effects on $\mathrm{CO}_{2}$ exchange in two grapevine cultivars. Progress in Photosynthesis Research 4, 181-4.

Downton, W. J. S., Grant, W. J. R., and Loveys, B. R. (1987). Diurnal changes in the photosynthesis of field-grown grape vines. New Phytologist 105, 71-80.

Düring, H. (1976). Untersuchungen zur Umweltabhängigkeit der stomatären Transpiration bei Reben. I. Beleuchtungstärke and Luftfeuchtigkeit. Vitis 15, 82-7.

Düring, H. (1987). Stomatal responses to alterations of soil and air humidity in grapevines. Vitis 26, 9-18.

Düring, H., and Loveys, B. R. (1982). Diurnal changes in water relations and abscisic acid in field grown Vitis vinifera cultivars. I. Leaf water potential components and leaf conductance under humid temperate and semiarid conditions. Vitis 21, 223-32.

Farquhar, G. D., Schulze, E.-D., and Küppers, M. (1980). Responses to humidity by stomata of Nicotiana glauca $\mathrm{L}$. and Corylus avellana L. are consistent with the optimisation of carbon dioxide uptake with respect to water loss. Australian Journal of Plant Physiology 7, 315-27.

Field, C. B. (1987). Leaf-age effects on stomatal conductance. In 'Stomatal Function'. (Eds E. Zeiger, G. D. Farquhar and I. R. Cowan.) pp. 367-84. (Stanford Univ. Press: Stanford, California.)

Giulivo, C., and Ramina, A. (1981). Studies on water relations of grapevines (Vitis vinifera). Acta Horticulturae 119, 109-21. 
Hall, A. E., and Schulze, E.-D. (1980). Stomatal response to environment and a possible interrelation between stomatal effects on transpiration and $\mathrm{CO}_{2}$ assimilation. Plant, Cell and Environment 3, 467-74.

Henderson-Sellers, B. (1984). A new formula for latent heat of vaporization of water as a function of temperature. Quarterly Journal of the Royal Meteorological Society 110, 1186-90.

Jarvis, P. G. (1975). Water transfer in plants. In 'Heat and Mass Transfer in the Biosphere'. (Eds D. A. De Vries and N. H. Afgan.) pp. 369-94. (Scripta Book Co.: Washington.)

Jarvis, P. G. (1976). The interpretation of the variations in leaf water potential and stomatal conductance found in canopies in the field. Philosophical Transactions of the Royal Society of London B 273, 593-610.

Katerji, N., and Daudet, F. A. (1986). Etude in situ du fonctionnement hydrique et photosynthétique d'une vigne conduite en lyre. Agronomie 6, 709-16.

Klepper, B. (1968). Diurnal pattern of water potential in woody plants. Plant Physiology 43, 1931-4.

Kliewer, W. M., Freeman; B. M., and Hossom, C. (1983). Effect of irrigation, crop level and potassium fertilization on Carignane vines. I. Degree of water stress and effect on growth and yield. American Journal of Enology and Viticulture 34, 186-96.

Kriedemann, P. E. (1978). Vineleaf photosynthesis. In 'Quality of the Vintage'. (Ed. Oenological and Viticultural Research Institute in Stellenbosch.) O.I.V. International Symposium, 14-21 February 1977, Cape Town, South Africa. pp. 67-87.

Kriedemann, P. E., and Smart, R. E. (1971). Effects of irradiance, temperature and leaf water potential on photosynthesis of vine leaves. Photosynthetica 5, 6-15.

Lange, O. L., and Meyer, A. (1979). Mittäglischer Stomataschluss bei Aprikose (Prunus armeniaca) und Wein (Vitis vinifera) im Freiland trozt guter Bodenwasser-Versorgung. Flora 168, 511-28.

Larsen, F. E., Higgins, S. S., and Al Wir, M. E. (1989). Diurnal water relations of apple, apricot, grape, olive and peach in an arid environment (Jordan). Scientia Horticulturae 39, 211-22.

Liu, W. T., Wenkert, W., Allen, L. H., and Lemon, E. R. (1978). Soil-plant water relations in a New York vineyard: resistances to water movement. Journal of the American Society for Horticultural Science 103, 226-30.

Loveys, B. R., and Düring, H. (1984). Diurnal changes in water relations and abscisic acid in fieldgrown Vitis vinifera cultivars. II. Abscisic acid changes under semi-arid conditions. New Phytologist 97, 37-47.

Meidner, H. (1983). Our understanding of plant water relations. Journal of Experimental Botany 34, 1606-18.

Meinzer, F. C., and Grantz, D. A. (1990). Stomatal and hydraulic conductance in growing sugarcane: stomatal adjustment to water transport capacity. Plant, Cell and Environment 13, 383-8.

Meinzer, F. C., Sharifi, M. R., Nilsen, E. T., and Rundel, P. W. (1988). Effects of manipulation of water and nitrogen regime on the water relations of the desert shrub Larrea tridentata. Oecologia 77, 480-6.

Montenegro, G., Araya, S., Aljaro, M. E., and Avila, G. (1982). Seasonal fluctuations of vegetative growth in roots and shoots of central Chilean shrubs. Oecologia 53, 235-7.

Natali, S., Xiloyannis, C., and Castagneto, M. (1985). Effect of soil water content on leaf water potential and stomatal resistance of grapevine (Vitis vinifera) grafted on different rootstocks. Acta Horticulturae 171, 331-40.

Passioura, J. B. (1986). Resistance to drought and salinity: avenues for improvement. Australian Journal of Plant Physiology 13, 191-201.

Riou, C., Pieri, P., and Valancogne, C. (1987). Variation de la vitesse du vent à l'intérieur et au-dessus d'une vigne. Agricultural and Forest Meteorology 39, 143-54.

Rogers, W. S., and Head, G. C. (1969). Factors affecting the distribution and growth of roots of perennial woody species. In 'Root Growth'. (Ed. W. D. Whittington.) pp. 280-95. (Butterworths: London.)

Saliendra, N. Z., and Meinzer, F. C. (1989). Relationship between root/soil hydraulic properties and stomatal behavior in sugarcane. Australian Journal of Plant Physiology 16, 241-50.

Salleo, S., and Lo Gullo, M. A. (1985). Hydraulic architecture of plants in the Mediterranean environment. Annali di Botanica 43, 257-74.

Salleo, S., Lo Gullo, M. A., and Oliveri, F. (1985). Hydraulic parameters measured in 1-year old twigs of some Mediterranean species with diffuse-porous wood: changes in hydraulic conductivity and their possible functional significance. Journal of Experimental Botany 36, 1-11. 
Schultz, H. R., and Matthews, M. A. (1988a). Vegetative growth distribution during water deficits in Vitis vinifera L. Australian Journal of Plant Physiology 15, 641-56.

Schultz, H. R., and Matthews, M. A. (1988b). Resistance to water transport in shoots of Vitis vinifera L. Relation to growth at low water potential. Plant Physiology 88, 718-24.

Schulze, E.-D. (1986). Whole-plant responses to drought. Australian Journal of Plant Physiology 13, 127-41.

Schulze, E.-D., Robichaux, R. H., Grace, J., Rundel, P. W., and Ehleringer, J. R. (1987a). Plant water balance. BioScience 37, 30-7.

Schulze, E.-D., Turner, N. C., Gollan, T., and Shackel, K. A. (1987b). Stomatal responses to air humidity and to soil drought. In 'Stomatal Function'. (Eds E. Zeiger, G. D. Farquhar and I. R. Cowan.) pp. 311-21. (Stanford Univ. Press: Stanford, California.)

Smart, R. E. (1974). Aspects of water relations of the grapevine (Vitis vinifera). American Journal of Enology and Viticulture 25, 84-91.

Sperry, J. S., Holbrook, N. M., Zimmermann, M. H., and Tyree, M. T. (1987). Spring filling of xylem vessels in wild grapevine. Plant Physiology 83, 414-17.

Tenhunen, J. D., Reynolds, J. F., Lange, O. L., Dougherty, R. L., Harley, P. C., Kümmerow, J., and Rambal, S. (1989). QUINTA: a physiologically-based growth simulator for drought adapted woody plant species. In 'Biomass Production by Fast-Growing Trees'. (Eds J. S. Pereira and J. J. Landsberg.) pp. 135-68. (Kluwer Acad. Press: Dordrecht.)

Turner, N. C. (1986). Crop water deficits: a decade of progress. Advances in Agronomy 39, 1-51.

Turner, N. C., Schulze, E.-D., and Gollan, T. (1984). The responses of stomata and leaf gas exchange to vapour pressure deficits and soil water content. I. Species comparisons at high soil water contents. Oecologia (Berlin) 63, 338-42.

Whitehead, D., Jarvis, P. G., and Waring, R. H. (1984). Stomatal conductance, transpiration, and resistance to water uptake in a Pinus sylvestris spacing experiment. Canadian Journal of Forest Research 14, 692-700.

Winkel, T., and Rambal, S. (1990). Stomatal conductance of some grapevines growing in the field under Mediterranean environment. Agricultural and Forest Meteorology 51, 107-21.

Manuscript received 8 May 1992, accepted 10 November 1992 